\title{
MULTIPLE-SCALE ROOST HABITAT COMPARISONS OF FEMALE MERRIAM'S WILD TURKEYS IN THE SOUTHERN BLACK HILLS, SOUTH DAKOTA
}

\author{
Daniel J. Thompson ${ }^{1}$, Mark A. Rumble ${ }^{2}$, Lester D. Flake ${ }^{3}$, and Chad P. Lehman ${ }^{3}$
}

\begin{abstract}
Because quantity and quality of roosting habitat can affect Merriam's Wild Turkey (Meleagris gallopavo merriami) distribution, we described habitat characteristics of Merriam's turkey roost sites in the southern Black Hills of South Dakota. Varying proportions of Merriam's turkeys in the southern Black Hills depended on supplemental feed from livestock operations during the 2 winters of our study, whereas the remainder wintered in forested habitat away from supplemental feed. We compared characteristics of roost habitat occupied by female turkeys from both groups. We located turkeys with radio-transmitters in the early morning and late evening to find roost sites. Female Merriam's turkeys in the southern Black Hills roosted exclusively in ponderosa pine trees, primarily on the upper portions of ridges on easterly aspects. Generally, trees $>30 \mathrm{~cm}$ diameter at breast height (dbh) were chosen for roosting, but turkeys also roosted in trees with smaller dbh. During winter months, turkeys that relied on supplemental feeding roosted adjacent to the ranch-farmstead where the supplemental food was located. Generally, these turkeys used the same roost site(s) throughout the winter, whereas turkeys that remained in the forest during winter used multiple roost sites. We suggest maintaining stands of trees $>30 \mathrm{~cm}$ dbh on the upper portions of easterly aspects to provide suitable roosting habitat for female Merriam's Wild Turkeys in the southern Black Hills.
\end{abstract}

Key words: Merriam's Wild Turkey, Meleagris gallopavo merriami, roost, roost habitat, supplemental feeding, Black Hills, South Dakota.

Distribution, disturbance, and scarcity of suitable roost sites may affect the distribution of Merriam’s Wild Turkeys (Meleagris gallopavo merriami; Ligon 1946, Boeker and Scott 1969, Scott and Boeker 1975). Generally, ponderosa pine (Pinus ponderosa) trees $>40 \mathrm{~cm}$ diameter at breast height (dbh) with evenly spaced horizontal branches are chosen for roosts by Merriam's turkeys in the Southwest (Boeker and Scott 1969, Mollohan et al. 1995) and Montana (Jonas 1966). However, in the central Black Hills, South Dakota, Merriam's turkey roost trees averaged $35 \mathrm{~cm}$ dbh and were documented as small as $23 \mathrm{~cm}$ dbh (Rumble 1992). Merriam's turkeys will also use large Douglasfir (Pseudotsuga menziesii), white fir (Abies concolor), cottonwood (Populus spp.), and American basswood (Tilia americana) for roosts (Hoffman 1968, Mackey 1984, Lutz and Crawford 1987, Flake et al. 1995). Other habitat characteristics and factors potentially affecting roost-site selection include density of trees surrounding the roost, location on slope, overstory canopy cover, percent slope, and accessibility to the roost (Rumble 1992).
Merriam's Wild Turkeys were introduced into the Black Hills of South Dakota in the late 1940s and early 1950s (Peterson and Richardson 1975, Flake et al. 2006). The turkey population flourished, suggesting that the habitat in the Black Hills suited introduced Merriam's turkeys. In the central Black Hills, Merriam's turkey roost characteristics differed from those in the southwestern United States (Boeker and Scott 1969, Mollohan et al. 1995). The southern Black Hills are more arid than the central and northern regions of the Black Hills (Orr 1959) and have a more open understory, and although the forested habitat of the Black Hills is fairly contiguous, trees $>40 \mathrm{~cm}$ dbh are rare. During the winter months in this region of the Black Hills, many flocks of turkeys used food resources associated with livestock feeding, centralizing daily activities within or near cattle feeding operations. As these turkeys become reliant on waste grain associated with ranches or farmsteads, their daily movements and activities (i.e., roosting) may be affected by the ease of obtaining winter forage. Roosting behavior of avian species is generally

\footnotetext{
${ }^{1}$ Department of Wildlife and Fisheries Sciences, South Dakota State University, Brookings, SD 57007-1696. E-mail: daniel.thompson@sdstate.edu

${ }^{2}$ Forest and Grassland Research Laboratory, Rocky Mountain Research Station, 8221 South Highway 16, Rapid City, SD 57702.

${ }^{3}$ Department of Wildlife and Fisheries Sciences, South Dakota State University, Brookings, SD 57007-1696.
} 
considered to be a tradeoff between predation avoidance and thermoregulatory benefits (Walsberg and King 1980, Caro 2005), especially during the winter. Our primary research objective was to quantify Merriam's Wild Turkey roost habitat at multiple scales in the southern Black Hills of South Dakota. Multiscalar quantification of variables associated with roost-site habitat may provide insight into vegetative characteristics preferred for roost sites and allow for in-depth discussion related to Merriam's turkey roost-site selection. Wild Turkeys are increasingly becoming reliant on supplemental winter feed associated with farmsteads (Vander Haegen et al. 1989, Wunz 1992, Lehman et al. 2007). A secondary objective of our study was to compare roost-habitat characteristics between forest-dwelling and farmstead-reliant turkeys. We hypothesized that the fidelity to waste grain supplements may supercede habitat preferences related to roost-site selection.

\section{Methods}

\section{Study Area}

The study area was within the southern Black Hills physiographic region of southwestern South Dakota (Ensz 1990) and covered about $2076 \mathrm{~km}^{2}$ of public and private land in Custer and Pennington counties, South Dakota. Approximately $60 \%$ of this montane area was forested and managed mainly for timber production (Ensz 1990). General topography consisted of open meadow valleys, shallow to deep drainages, gentle to steep slopes, and sheer canyon walls. The study area is more xeric than the central and northern Black Hills, with an average annual precipitation of $46 \mathrm{~cm}$. Average daily temperature ranged from -6.6 to $18.1^{\circ} \mathrm{C}$ (Ensz 1990). Elevations ranged from 930 to $1627 \mathrm{~m}$.

The forested vegetation of the study area was dominated by ponderosa pine. In the southern Black Hills, ponderosa pine tends to spread into surrounding grasslands along a pine-grassland ecotone (Gartner and Thompson 1973). Other forest types included eastern cottonwood (Populus deltoides), quaking aspen (Populus tremuloides), and green ash (Fraxinus pennsylvanica) that together comprised $<10 \%$ of the study area. The predominant understory shrub was common juniper (Juniperus communis). Other shrub species included western snowberry
(Symphoricarpos occidentalis), serviceberry (Amelanchier alnifolia), chokecherry (Prunus virginiana), and bearberry (Arctostaphylos uvaursi). Native grasses included western wheatgrass (Agropyron smithii), green needlegrass (Stipa virginianus), needle and thread (Stipa comata), little bluestem (Schizachyrium scoparium), and grama (Bouteloua spp.) (Larson and Johnson 1999). Primary agriculture and livestock operations consist of cattle ranching on private land parcels within the southern Black Hills region, as well as summer forest grazing on allotments throughout the Black Hills National Forest (Ensz 1990).

\section{Capture and Roost-Site Location}

Wild Turkeys were captured using rocket nets (Thompson and Delong 1967, Hawkins et al. 1968) and drop nets (Glazener et al. 1964) from 1 January to 15 March 2001 and 2002. Female turkeys were fitted with 98-g backpackmounted radio-transmitters and immediately released at the capture site.

Aided by a handheld Yagi antenna, we located and followed radio-marked females to the roost at least once each week. We located all radio-marked birds systematically to ensure that individuals were monitored proportionately throughout the sampling period. We maintained adequate distance so as not to disturb the birds until they had entered the roost, at which point we approached the roost site to observe the location and determine which tree(s) contained turkeys. Roost sites were marked with plastic flagging and recorded with a global positioning system (GPS). We identified trees used for roosting by direct observation. If there was uncertainty as to which tree was used as a roost, the presence of fresh droppings directly below the roost tree was used as validation (Lutz and Crawford 1987). All vegetation measurements were collected during diurnal portions of the day when turkeys were not present at the roost site.

\section{Vegetation Measurements}

We characterized forest vegetation at multiple scales that represented a hierarchical scale of habitat selection (Johnson 1980). To evaluate 1st-order habitat selection, we used a stratified random-sampling design based on vegetation structural stages (Buttery and Gillam 1983) to estimate habitat availability from random points (study-area random sites) in the forested 
portions of the study area. We quantified vegetation characteristics within the forest stand at a site located $100 \mathrm{~m}$ from the roost by using a pseudorandom design that was constrained to be within the same forested stand; these within-stand sites were referred to as dependent-random sites. We compared dependentrandom sites to roost sites in order to represent 2nd-order selection (Johnson 1980). Roost habitat available within the roost site was estimated by quantifying vegetative characteristics at a center plot surrounding the roost tree(s) and at 2 adjacent plots $30 \mathrm{~m}$ from the roost tree along the contour of the slope. We compared characteristics of the center plot containing the roost tree(s) to the adjacent plots in order to evaluate 3rd-order selection (Johnson 1980).

We used a variable-radius with a fixedradius design to characterize the forest vegetation at each plot. The variable radius was determined using a 10-factor prism for trees $>15.2 \mathrm{~cm} \mathrm{dbh}$; trees $\leq 15.2 \mathrm{~cm}$ dbh were measured in a 5.02-m fixed-radius plot. We recorded species and dbh for each tree in the plot. A clinometer was used to estimate percent slope, and a downhill compass bearing at the center plot was used to estimate aspect. Overstory canopy cover (OCC) was estimated by recording the presence or absence of overstory canopy at $1-\mathrm{m}$ intervals along two $25-\mathrm{m}$ transects radiating from the center plot and then calculating an overall grid percentage of canopy cover. We classified the location of roost sites on the slope into 1 of 6 categories: ridge, top $25 \%$, upper $25 \%$, lower $25 \%$, bottom $25 \%$, and bottom. The ridge peak was considered "ridge," the top $75 \%$ to the ridge was "top 25\%," the midpoint of the ridge to the top $75 \%$ of the ridge was "upper $25 \%$," and so on to the valley, which was considered "bottom." We estimated the location of roosting birds in trees and classified their location into 1 of 4 vertical quartiles. We estimated the distance between lateral branches of the roost trees to the nearest $25 \mathrm{~cm}(0.25 \mathrm{~m})$. Downed woody debris (metric tons $\cdot \mathrm{ha}^{-1}$ ) below the roost tree was estimated using a photoseries guide (United States Forest Service, Rocky Mountain Region 1982), from which we visually estimated the amount of debris on the forest floor by diameter of downed woody material below the roost. We also estimated the distance (to the nearest $1 \mathrm{~m}$ ) from the roost tree to the nearest opening wide enough for a turkey to enter the roost without having to avoid overstory or understory vegetation.

Roost sites used from 15 December through 15 April were classified as winter roosts, whereas roosts used outside these dates were classified as spring-summer roosts. Roosts of radio-marked females that were observed feeding on supplemental grain more than twice during the winter were considered roosts of farmstead-reliant birds. We used this classification to compare farmstead-reliant roost sites to roost sites of those female turkeys that remained in the forest during the winter. Radio-marked turkeys were located a least 6 times per week in order to document reliance on supplemental grain and to make sure commingling did not occur between forest and farmstead-reliant turkey flocks during the winter.

\section{Data Analysis}

Data for tree species and dbh were summarized and used to calculate tree density and average dbh for each plot. For subsequent analyses comparing study-area random sites and roost dependent-random sites with roost sites, plots were averaged for estimates at sites. OCC, aspect, slope, and woody debris were summarized to calculate values for each site. Data analyses were conducted using SPSS (SPSS, Inc. 2000) and SAS (SAS Institute, Inc. 2000) software. We set $\alpha$ at $\leq 0.10$ to determine statistical significance. The liberal $\alpha$-level (rather than the default of 0.05) was chosen in order to decrease the chance of perpetuating type II errors in forest management recommendations, which could result in the alteration of forest stands important as Merriam's turkey roost habitat.

\section{Roost Sites vs. Study Area Random Sites}

We used multiresponse permutation procedures (MRPP) and $t$ tests (Mielke and Berry 2001) to compare mean values of vegetative and forest stand characteristics between roost sites and random sites. MRPP procedures test for differences in variance between 2 or more groups and are also appropriate for data that fail to meet normal distribution requirements (Mielke and Berry 2001). Because of the way our habitat components were separated between groups (i.e., 3 plots per site; roost sites, 
TABLE 1. Habitat characteristics of female Merriam's Wild Turkey roosts in the southern Black Hills, South Dakota, $2001-2002$.

\begin{tabular}{|c|c|c|c|c|c|c|}
\hline & \multicolumn{2}{|c|}{ Random sites $(n=119)$} & \multicolumn{2}{|c|}{$\begin{array}{c}\text { Dependent- } \\
\text { random sites }(n=53)\end{array}$} & \multicolumn{2}{|c|}{ Roost sites $(n=53)$} \\
\hline & $\bar{x}$ & $s_{\bar{x}}$ & $\bar{x}$ & $s_{\bar{x}}$ & $\bar{x}$ & $s_{\bar{x}}$ \\
\hline Overstory canopy cover (\%) & $39.40^{\mathrm{a}}$ & 2.08 & $38.42^{\mathrm{b}}$ & 2.98 & $60.72^{\mathrm{ab}}$ & 1.11 \\
\hline Slope $(\%)$ & $11.80^{\mathrm{a}}$ & 0.70 & 18.15 & 1.63 & $21.50^{\mathrm{a}}$ & 1.64 \\
\hline Woody debris (tons $\cdot$ acre $^{-1}$ ) & $9.63^{\mathrm{a}}$ & 0.62 & 6.04 & 1.48 & $6.02^{\mathrm{a}}$ & 0.42 \\
\hline Distance to opening (m) & $\mathrm{n} / \mathrm{a}$ & $\mathrm{n} / \mathrm{a}$ & 15.42 & 2.97 & 13.26 & 2.23 \\
\hline
\end{tabular}

asite values differed between random sites and roost sites $(P<0.10)$.

bSite values differed between dependent-random sites and roost sites $(P<0.10)$.

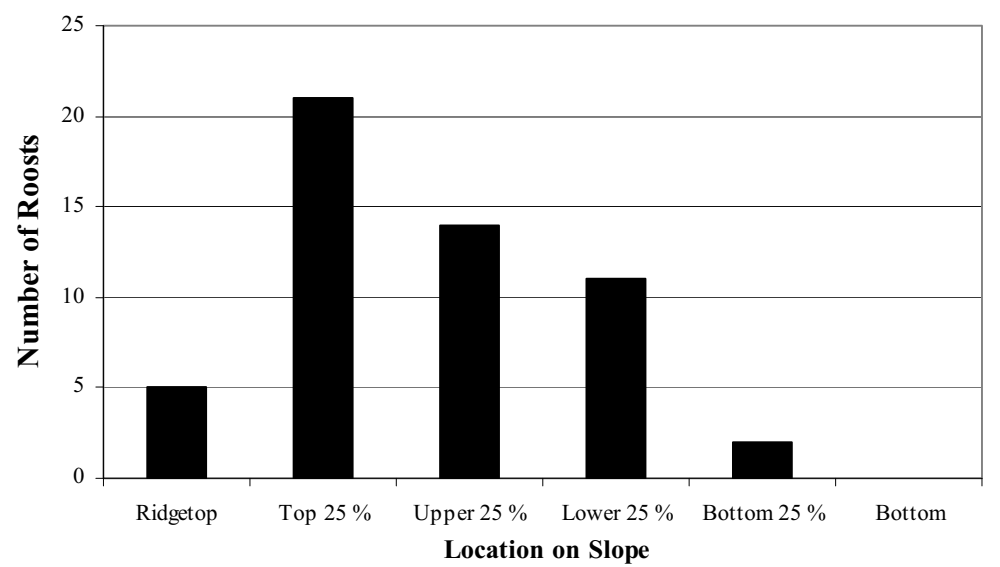

Fig. 1. Location on slope of female Merriam's Wild Turkey roosts in the southern Black Hills, South Dakota, 2001-2002.

dependent-random sites, and study-area random sites), MRPP represented an appropriate comparison and analysis technique. For analyses of roost-site selection by female Wild Turkeys across the study area, we included a weight factor to accommodate deviations from proportional sampling among strata (Cochran 1977) in the study area. Each random site was assigned a weight equalling $P_{i} \times N_{t} / N_{i}$, where $P_{i}$ was the proportion of the entire study area composed of a particular stratum $(i$; vegetation structural stage), $N_{t}$ was the total number of random samples, and $N_{i}$ was the number of random samples in a particular stratum $(i)$. Sites where we observed Merriam's turkey roosts received a weight of 1.0. We used chisquare tests of independence to compare aspect between roost sites and random sites.

Roost Sites vs. Dependent-Random Sites and Roost Plot Comparisons

We used paired $t$ tests to compare vegetation and forest stand characteristics between roost sites and dependent-random sites. We used chi-square tests of independence to compare aspect between roost sites and dependent-random sites. MRPP was used to compare forest stand characteristics among roost plots.

Seasonal and Forest vs.

Farmstead-Reliant Comparisons

Using MRPP and chi-square analyses, we compared winter roost characteristics between farmstead-reliant birds and birds that remained in the forest.

\section{RESUlTS}

\section{Roost Sites vs. Study-Area Random Sites (1st-Order Selection)}

Roost sites $(n=53)$ had higher overstory canopy cover $\left(60.72 \%, s_{\bar{x}}=1.11\right)$ compared to study-area random sites $\left(n=119 ; 39.40 \%, s_{\bar{x}}\right.$ $=2.08$; Table 1 ) and less woody debris below the roost $\left(6.02\right.$ tons $\cdot$ acre $\left.^{-1}, s_{\bar{x}}=0.42\right)$ compared to study-area random sites (9.63 tons - 


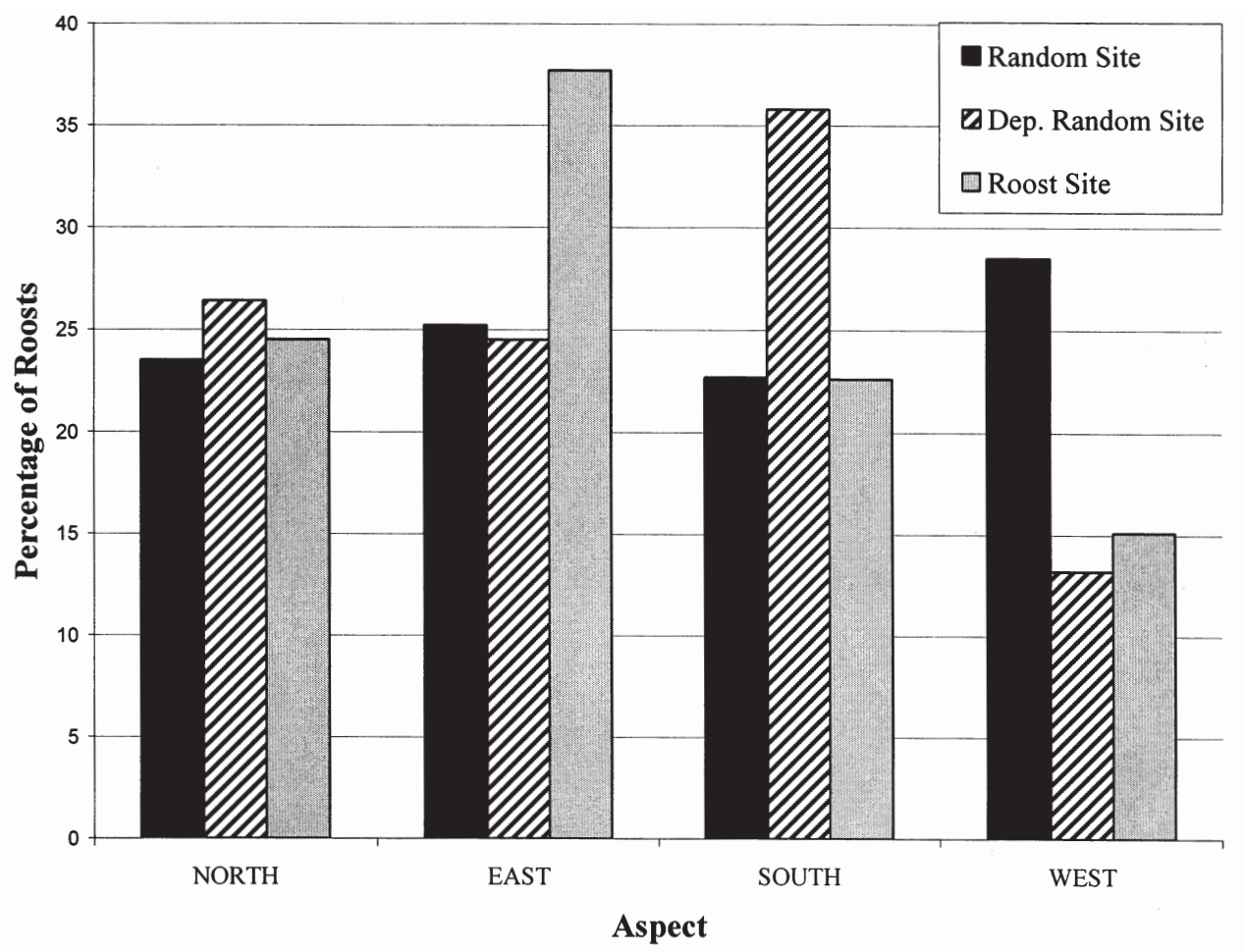

Fig. 2. Comparison of aspect between random sites, dependent-random sites, and roost sites in the southern Black Hills, South Dakota, 2001-2002.

acre $^{-1}, s_{\bar{x}}=0.62$; Table 1). Roost sites contained larger trees $\left(27.9 \mathrm{~cm}, s_{\bar{x}}=0.68\right)$ and had a lower density of trees (381.01 trees • $\left.\mathrm{ha}^{-1}, s_{\bar{x}}=33.43\right)$ than the habitat available throughout the study area (Table 2). Merriam's turkey roosts were primarily located in the top $25 \%$ of the ridge $(39.6 \%)$, with the majority of roost sites occurring in the upper to top $25 \%$ of the ridge (Fig. 1). Roosts were located on steeper slopes (Table 1), predominantly on east-facing aspects (Fig. 2). The aspect of turkey roost locations differed slightly between random sites and roost sites $\left(\chi^{2}=6.24\right.$, $\mathrm{df}=3, P=$ 0.09). Female Merriam's turkeys in the southern Black Hills selected roosts on east-facing aspects (Fig. 2) and limited roosting on western slopes $\left(\chi^{2}=6.24\right.$, $\left.\mathrm{df}=1, P=0.01\right)$.

\section{Roost Sites vs. Dependent-Random Sites (2nd-Order Selection)}

Overstory canopy cover was higher at roost sites $\left(60.72 \%, s_{\bar{x}}=1.11\right)$ compared to dependent-random sites $\left(38.42 \%, s_{\bar{x}}=2.98 ; n=53\right)$. No differences between roost sites and dependent-random sites were evident for slope, woody debris, and distance to nearest opening (Table 1). The average dbh of trees at roost sites and dependent-random sites did not differ $\left(27.9\left[s_{\bar{x}}=0.68 \mathrm{~cm}\right]\right.$ vs. $\left.26.04\left[s_{\bar{x}}=1.14 \mathrm{~cm}\right]\right)$. However, density of trees was lower at roost sites (381.01 trees $\left.\cdot \mathrm{ha}^{-1}, s_{\bar{x}}=33.43\right)$ compared to dependent-random sites $(640.71$ trees $\cdot$ ha $\left.^{-1}, s_{\bar{x}}=128.44\right)$. Female Merriam's turkeys selected easterly aspects (Fig. 2) and utilized southern slopes for roosting less than they were available $\left(\chi^{2}=5.74, \mathrm{df}=1, P=0.02\right)$.

\section{Center Roost Plot vs. Adjacent Plots (3rd-Order Selection)}

We found larger trees directly surrounding the roost $\left(29.9 \mathrm{~cm}, s_{\bar{x}}=1.09\right)$ and a lower density of trees (259.73 trees $\left.\cdot \mathrm{ha}^{-1}, s_{\bar{x}}=34.74\right)$ at the center roost plot $(n=53)$ compared to adjacent plots $(n=53)$ located $30 \mathrm{~m}$ from the roost $\left(26.94 \mathrm{~cm}, s_{\bar{x}}=1.34 ; 444.46\right.$ trees $\cdot \mathrm{ha}^{-1}$, $\left.s_{\bar{x}}=73.40\right)$. Therefore, we compared the center roost plot with results from the dependentrandom and random sites. When compared to the center roost plots at both study-area random and dependent-random sites, trees in the 
TABLE 2. Forest stand characteristics of female Merriam's Wild Turkey roosts in the southern Black Hills, South Dakota, 2001-2002.

\begin{tabular}{llcrrr}
\hline & \multicolumn{2}{c}{$\mathrm{dbh}(\mathrm{cm})$} & & \multicolumn{2}{c}{ Tree density $\left(\right.$ trees $\left.\cdot \mathrm{ha}^{-1}\right)$} \\
\cline { 2 - 3 } & \multicolumn{1}{c}{} & \multicolumn{1}{c}{$s_{\bar{x}}$} & & $\bar{x}$ & $s_{\bar{x}}$ \\
\hline Random sites $(n=119)$ & $23.6^{\mathrm{ad}}$ & 0.62 & & $1059.56^{\mathrm{ad}}$ & 70.25 \\
Dependent-random sites $(n=53)$ & $26.04^{\mathrm{d}}$ & 1.14 & $640.71^{\mathrm{bd}}$ & 128.44 \\
Roost sites $(n=53)$ & $27.9^{\mathrm{a}}$ & 0.68 & $381.01^{\mathrm{ab}}$ & 33.43 \\
Adjacent plots $(n=53)$ & $26.94^{\mathrm{c}}$ & 1.34 & & $444.46^{\mathrm{c}}$ & 73.40 \\
Roost plots $(n=53)$ & $29.90^{\mathrm{abcd}}$ & 1.09 & & $259.73^{\mathrm{abcd}}$ & 34.74 \\
\hline
\end{tabular}

aStand values differed between random sites and roost sites $(P<0.10)$.

bStand values differed between dependent-random sites and roost sites $(P<0.01)$

'Stand values differed between roost plots and adjacent plots $(P<0.01)$

dStand values differed between roost plots and other groups $(P<0.01)$.

center plot of roost sites were larger $(29.90 \mathrm{~cm}$, $s_{\bar{x}}=1.09$; Table 2). Roost plots had the lowest tree densities of all sites (Table 2).

\section{Roost Tree Characteristics}

Merriam's Wild Turkeys roosted exclusively in ponderosa pines. Roost trees averaged 34.3 $\mathrm{cm} \mathrm{dbh}\left(s_{\bar{x}}=0.73\right)$; however, there was a large range in size of trees used for roosts (16.1$61.8 \mathrm{~cm} \mathrm{dbh})$. Spacing between branches of roost trees averaged $1.3 \mathrm{~m}\left(s_{\bar{x}}=0.04\right)$. Turkeys roosted in the top half of the tree $96 \%$ of the time, and $69 \%$ of roosts occurred at the $50 \%$ $75 \%$ height of the tree. Average dbh of roost trees was larger than average dbh of trees in the surrounding plot $(P<0.01)$; however, 36\% of roost plots also contained trees with larger dbh than the tree(s) chosen for roosting.

\section{Seasonal Roost Comparisons}

Average dbh of the forest stand at roost sites was nearly identical between winter roost sites and roost sites used during the summer and spring $(P>0.37)$. Winter roost sites had tree densities similar to those of spring-summer sites $(P=0.14)$. Winter roost sites included more roost trees per site ( 5 roost trees per site) than spring-summer sites (1.6 roost trees per site). Overstory canopy cover was higher $(P=$ $0.04)$ at winter roost sites $\left(63.03 \mathrm{~cm}, s_{\bar{x}}=1.52\right)$ than at spring-summer roost sites $\left(58.3 \mathrm{~cm}, s_{\bar{x}}\right.$ $=2.02$ ).

Forest Turkeys vs.

Farmstead-Reliant Turkeys

When comparing vegetation characteristics of roost sites between forest and farmsteadreliant birds, we found only one difference: trees in the center roost plot were larger $(P=$ $0.02)$ for farmstead-reliant turkeys $(31.75 \mathrm{~cm}$, $\left.s_{\bar{x}}=0.58\right)$ compared to forest turkeys (27.18 $\left.\mathrm{cm}, s_{\bar{x}}=0.52 \mathrm{~cm}\right)$. Turkeys that roosted near, or were associated with, supplemental feed at farmsteads showed high fidelity to winter roost sites between years and used only 1-2 roost sites for the entire winter season once they incorporated waste grain into their feeding habits.

\section{Discussion}

Understanding habitat selection processes of animals at multiple scales helps biologists develop management recommendations for forest managers. Increasingly, forest managers are considering ecological phenomena at broad environmental scales (MacFaden and Capen 2002). Based on our findings, it appears that female Merriam's turkeys in the southern Black Hills selected roost sites based on microhabitat vegetative and topographic characteristics at the roost site as well as particular characteristics of the tree(s) within the site selected for roosting. Turkeys sought areas for roosting that consisted of larger trees and had lower tree densities within the forest complex. Larger trees provided the characteristic open canopies and branch spacing suggested in other studies as one of the driving factors of roost-site selection (Hoffman 1968, Boeker and Scott 1969, Rumble 1992). Decreased tree densities with less downed woody debris on the forest floor suggested selection for open areas that provided easier access for roost exit and entry.

Selection for easterly aspects in the southern Black Hills suggested that other factors are also important in the choice of roost sites. Boeker and Scott (1969) indicated that roost sites on easterly aspects in the upper portions of ridges may have been selected for their early morning light, whereas Hoffman (1968) 
suggested that protection from prevailing weather from the northwest was important in selection of roosts in Colorado. Prevailing wind direction in our study was also westnorthwest (Local Climatological Data, Custer, SD). Although we did not measure wind velocity at actual roost sites, our data support the notion of roost-site selection to reduce wind exposure. Selecting roost sites with decreased wind velocities may have positive effects on thermoregulation (Walsberg and King 1980, Walsberg 1986). Wind shielding can decrease heat loss from convection up to 5 -fold in some birds (Walsberg 1986), primarily through reduced convection and an associated reduction in heat conduction from the body (Randall et al. 2002). Roosting in dense stands of overmature pines has been suggested as a strategy used by turkeys to reduce their exposure to the elements (Kilpatrick et al. 1988, Chamberlain et al. 2000). In Minnesota, Wild Turkeys chose winter roost sites with higher canopy coverage, larger diameter trees, and greater overstory tree-stem density (Ermer et al. 2006) than areas without roosts. Although birds may have selected roost sites to reduce wind exposure and heat loss, it appeared that other factors were also important for roost-site selection.

Predator avoidance has been suggested as a factor for nocturnal roost-site selection by avian species (Lack 1968, Caro 2005), and it may supercede thermoregulatory benefits in some cases (Walsberg and King 1980, Fisher et al. 2004). These 2 hypotheses for roost-site selection are partially supported by our data on female Merriam's turkeys in the southern Black Hills. Although turkeys selected sites that at least partially mitigated the effects of weather, they also roosted higher in tree canopies and away from the tree bowl. This negated thermoregulatory benefits but most likely enhanced detection and avoidance of mammalian predators such as bobcats (Lynx rufus; Walsberg and King 1980). The high overstory canopy cover found at roost sites could provide protection from nocturnal avian predators such as Great Horned Owls (Bubo virginianus), which are a significant source of mortality to Merriam's turkeys in the southern Black Hills (Lehman et al. 2007). Ample branch spacing could be important for exit from the roost as well as for entry. In the event of nocturnal avian predation attempts, uninhibited exit from a tree may decrease predation risk. Our observations in- dicated that turkeys readily pitched out of roost trees in the downhill direction when disturbed.

Characteristics of Merriam's turkey roost trees in the southern Black Hills were similar to those in the central Black Hills (Rumble 1992). Average diameter of roost trees is reported in several studies to be substantially greater in the southwestern and western United States (Hoffman 1968, Mackey 1984, Lutz and Crawford 1987). The fact that some roost plots in our study contained trees of larger dbh than the actual roost tree(s) suggests that the diameter of the trees is indicative of other characteristics sought by Merriam's turkeys, and that other site characteristics augment roost choice. This suggestion is supported by the occurrence of roosting in trees of only $23 \mathrm{~cm} \mathrm{dbh}$ (Rumble 1992) and $20 \mathrm{~cm}$ dbh (this study).

Multiple use of the same roost sites, sometimes referred to as traditional roosts, occurred mainly in the winter months by turkeys wintering near farmsteads. Turkeys relying on ranches or farmsteads for supplemental feed roosted close $(<200 \mathrm{~m})$ to the food source and usually went directly from the roost to the feed in the morning. Turkeys that remained in the forest during the winter months used more roost sites and occasionally used the same roost site for a few nights before moving to a new area. Merriam's turkeys that roosted in the forest were not restricted to a specific site for foraging, and upon selecting a new feeding site, they also chose a new roost site. Based on our results, the reliance on ranches and farmsteads for supplemental winter forage did not affect the preferential characteristics associated with roost-site selection of Merriam's female turkeys in the southern Black Hills.

\section{ManAGEMENT IMPLICATIONS}

The large range of tree size and the variety of locations chosen for roost sites by female Merriam's Wild Turkeys suggest that availability of suitable roost habitat is not restricting the distribution of Merriam's turkeys in the southern Black Hills. While thermoregulatory benefits appear to play a part in the selection of roosts, other elements of the roost-selection process seem to compromise the thermoregulatory benefits. To our knowledge, the issue of roost-site selection to reduce risk of predation has not been specifically evaluated for gallinaceous species. An improved working knowledge 
of the interactions between predator avoidance, thermoregulation, and forest habitat as they pertain to roosting behavior would prove beneficial for future research studies designed to evaluate selection and would increase the understanding of the factors affecting roost selection as they relate to habitat and population manipulation and management.

Forest management plans in the southern Black Hills should include a wide distribution of stands with approximately $60 \%$ overstory canopy cover and trees $>30 \mathrm{~cm} \mathrm{dbh}$. To provide for suitable well-distributed roosts, emphasis should be toward managing these stands on easterly aspects on the upper portions of ridges throughout the landscape.

\section{ACKNOWLEDGMENTS}

M. Rohlfing and C. Sexton assisted with data collection, and L. Fiala, L. Wood, and N. Westphal generously allowed access to their land. This research was supported by the South Dakota Department of Game, Fish and Parks; the Federal Aid to Wildlife Restoration Fund (Project W-75-R-38 No. 7599); South Dakota State University; McIntire-Stennis funding through the South Dakota Agricultural Experiment Station; the National Wild Turkey Federation; the South Dakota Chapter of the National Wild Turkey Federation; and the U.S. Rocky Mountain Research Station (01-CS11221609-180).

\section{Literature Cited}

Boeker, E.L., AND V.E. ScotT. 1969. Roost tree characteristics of Merriam's turkey. Journal of Wildlife Management 33:121-124.

Buttery, R.F., and B.C. GiLlam. 1983. Forest ecosystems. Pages 43-71 in R.L. Hoover and D.L. Wills, editors, Managing forested lands for wildlife. Colorado Division of Wildlife, in cooperation with USDA Forest Service, Rocky Mountain Region, Denver, CO.

CARo, T. 2005. Antipredator defenses in birds and mammals. University of Chicago Press, Chicago, IL.

Chamberlain, M.J., B.D. Leopold, and L.W. Burger. 2000. Characteristics of roost sites of adult Wild Turkey females. Journal of Wildlife Management 64: 1025-1032.

Cochran, W.G. 1977. Sampling techniques. 3rd edition. John Wiley \& Sons, New York.

Ensz, E.H. 1990. Soil survey of Custer and Pennington Counties, Black Hills Parts, South Dakota / United States Department of Agriculture, Soil Conservation Service.

Ermer, J.R., K.J. Haroldson, R.O. Kimmel, C.D. Dieter, P.D. Evenson, AND B.B. Berg. 2007. Characteristics of winter roost and activity sites of Wild Turkeys in
Minnesota. Proceedings of the National Wild Turkey Symposium 9:263-272.

Fisher, R.J., Q.F. Fletcher, C.K.R. Willis, and R.M. BRIGHAM. 2004. Roost selection and roosting behavior of male common nighthawks. American Midland Naturalist 151:79-87.

Flake, L.D., R.A. Craft, AND W.L. TuCKer. 1995. Vegetation characteristics of Wild Turkey roost sites during summer in south-central South Dakota. Proceedings of the National Wild Turkey Symposium 7:159-164.

Flake, L.D., C.P. Lehman, A.P. Leif, M.A. Rumble, AND D.J. Thompson. 2006. The Wild Turkey in South Dakota. SDEAS B747. South Dakota Department of Game, Fish and Parks; South Dakota Agricultural Experiment Station, Brookings.

Gartner, F.R., And W.W. Thompson. 1973. Fire in the Black Hills forest-grass ecotone. Proceedings of the Tall Timbers Fire Ecology Conference 12:37-68.

Glazener, W.C., A.S. Jackson, and M.L. Cox. 1964. The Texas drop-net turkey trap. Journal of Wildlife Management 28:280-287.

Hawkins, R.E., L.D. Martoglio, and G.G. Montgomery. 1968. Cannon-netting deer. Journal of Wildlife Management 34:231-233.

Hoffman, D.M. 1968. Roost sites and habits of Merriam's turkeys in Colorado. Journal of Wildlife Management 32:859-866.

Johnson, D.H. 1980. The comparison of usage and availability measurements for evaluating resource preference. Ecology 61:65-71.

JONAS, R. 1966. Merriam’s turkeys in southeastern Montana. Montana Game and Fish Department Technical Bulletin, No. 3. Helena, MT.

Kilpatrick, H.J., T.P. Husband, and C.A. Pringle. 1988. Winter roost site characteristics of eastern Wild Turkeys. Journal of Wildlife Management 52:461-463.

LACK, D. 1968. Ecological adaptations for breeding in birds. Methuen, London. 409 pp.

Larson, G.E., and J.R. Johnson. 1999. Plants of the Black Hills and Bear Lodge Mountains: a field guide with color photographs. South Dakota State University, Brookings.

Lehman, C.P., L.D. Flake, and M.A. Rumble. 2007. Survival and cause-specific mortality of Merriam's turkey females in the southern Black Hills. Proceedings of National Wild Turkey Symposium 9:295-301.

LigON, J.S. 1946. History and management of Merriam's Wild Turkey. New Mexico Game and Fish Commission. University of New Mexico Press, Albuquerque.

Lutz, R.S., AND J.A. Crawford. 1987. Seasonal use of roost sites by Merriam's Wild Turkey hens and henpoult flocks in Oregon. Northwest Science 61:174178.

MacFaden, S.W., and D.E. Capen. 2002. Avian habitat relationships at multiple scales in a New England forest. Forest Science 48:243-253.

MaCKEY, D.L. 1984. Roosting habitat of Merriam's turkeys in south-central Washington. Journal of Wildlife Management 48:1377-1382.

Mielke, P.W., Jr., and K.J. Berry. 2001. Permutation methods: a distance function approach. SpringerVerlag, New York.

Mollohan, C.M., D.R. Patton, and B.F. WaKeling. 1995. Habitat selection and use by Merriam's turkey in northcentral Arizona. A final report. Technical report 9, Arizona Game and Fish Department, Phoenix. 
ORR, H.K. 1959. Precipitation and stream flow in the Black Hills. USDA Forest Service, Rocky Mountain Forest and Range Experiment Station, Station Paper 44. Fort Collins, CO.

Peterson, L.E., And A.H. Richardson. 1975. The Wild Turkey in the Black Hills. Technical Bulletin No. 6, South Dakota Department of Game, Fish and Parks, Pierre.

Randall, D., W. Burggren, And K. French. 2002. Eckert animal physiology: mechanisms and adaptations. W.H. Freeman and Company, New York.

Rumble, M.A. 1992. Roosting habitat of Merriam's turkeys in the Black Hills, South Dakota. Journal of Wildlife Management 56:750-759.

SAS Institute, Inc. 2000. SAS/STAT user's guide. SAS Institute, Inc., Cary, NC.

ScotT, V.E., AND E.L. BoEKer. 1975. Ecology of Merriam’s Wild Turkey on the Fort Apache Indian Reservation. Proceedings of the National Wild Turkey Symposium 3:141-158.

SPSS, INC. 2000. SPSS statistics. SPSS, Inc., Chicago, IL. Thompson, M.C., And R.L. Delong. 1967. The use of cannon and rocket-projected nets for trapping shorebirds. Bird Banding 38:214-218.
United States Forest Service, Rocky Mountain Region. 1982. Photoseries for quantifying forest residues in the Black Hills ponderosa type, spruce type. AFM 83, Rocky Mountain Region, Denver, CO.

Vander Haegen, W.M., M.W. Sayre, and W.E. Dodge. 1989. Winter use of agricultural habitats by Wild Turkeys in Massachusetts. Journal of Wildlife Management 53:30-33.

WalsberG, G.E. 1986. Thermal consequences of roostsite selection: the relative importance of three modes of heat conservation. Auk 103:1-7.

WaLsBerg, G.E., AND J.R. KING. 1980. The thermoregulatory significance of the winter roost-sites selected by robins in eastern Washington. Wilson Bulletin 92: 33-39.

Wunz, G.A. 1992. Wild Turkeys outside their historic range. Pages 361-384 in J.G. Dickson, editor, The Wild Turkey: biology and management. Stackpole Books, Harrisburg, PA.

Received 4 September 2007 Accepted 30 June 2008 